Abstracted/indexed in Academic Search Complete, Asia Journals Online, Bangladesh Journals Online, Biological Abstracts, BIOSIS Previews, CAB Abstracts, Current Abstracts, Directory of Open Access Journals, EMBASE/Excerpta Medica, Google Scholar, HINARI (WHO), International Pharmaceutical Abstracts, Open J-gate, Science Citation Index Expanded, SCOPUS and Social Sciences Citation Index;

ISSN: $1991-0088$

\title{
Cytotoxicity study of some indophenines and isatin derivatives
}

\author{
Md. Mahbubul Hoque and Md. Rabiul Islam
}

Department of Chemistry, Jahangirnagar University, Savar, Dhaka 1342, Bangladesh.

\begin{tabular}{|c|c|}
\hline \multicolumn{2}{|l|}{ Article Info } \\
\hline Received: & 2 December 2007 \\
\hline Accepted: & 12 \\
\hline Available Online: & 25 April 2008 \\
\hline \multicolumn{2}{|c|}{ DOI: 10.3329/bjp.v3i1.828 } \\
\hline \multicolumn{2}{|c|}{$\begin{array}{l}\text { Cite this article: } \\
\text { Hoque MM, Islam MR. Cytotoxicity } \\
\text { study of some indophenines and isa- } \\
\text { tin derivatives. Bangladesh J Pharma- } \\
\text { col. 2008; } 3: 21-26 \text {. }\end{array}$} \\
\hline
\end{tabular}

\begin{abstract}
Eight indophenines were synthesized for the interest of studying biological activity especially for cytotoxicity. The cytotoxicity of some indophenines and some isatin derivatives was studied by the brine shrimp lethality bioassay. It was observed that all the indophenines from thiophene, thiazol and isatin derivatives showed potential cytotoxicity against brine shrimp nauplii and the structure activity relationships (SAR) of these compounds have been reported.
\end{abstract}

\section{Introduction}

Isatin (1H-indole-2,3-dione) and its derivatives possessing an indole nucleus have arose great attention in recent years due to their wide variety of biological activities and pharmacological studies as insecticides (Bahmaria and Deliwala, 1968), fungicides (Chen and Rhodes, 1996), anti-cancer (Holla et al., 2000) and antiinflammatory. Isatins are very important compounds due to their antifungal properties (Islam et al., 1998). Moreover, isatins are the synthetic precursors of some biologically important compounds such as quinoline 1, 2, 3-thiadiazoline (Ram et al., 1980). Besides that, the triazins [5, 6-b] indole-3-thione derivatives have attracted considerable attention in the field of medicine due to their antifungal, antimalarial and antiparasitic properties (Pal et al., 1991). Therefore, the research interest on isatins has expanded day by day. Because of the continuing interest about isatins and its derivatives (Saha et al., 1992), the present study aims at the synthesis of some indophenines from isatins, thiophene, and thiazol. This work has been carried out from the synthetic point of view along with their biological (Islam et al., 1990) property especially cytotoxicity by brine shrimp lethality bioassay (Meyer et al., 1982; Solis et al., 1993).

\section{Materials and Methods}

Physical and spectral data of the compounds were recorded on a Fischer Johns electrothermal melting point apparatus by thin disc method, on a DR-8001 Shimadzu FT-IR spectrophotometer, on a WP-400 NMR spectrophotometer using DMSO- $\mathrm{d}_{6}$ as the solvent with tetramethylsilane as internal standard and on a Kratas MS-25 using DH-88 data system.

Isatin and substituted isatins $\mathbf{1 a}, \mathbf{1 b}$ and $\mathbf{1 c}$ (Sandmeyer, 1919) were synthesized from the condensation of corresponding aniline with chloralhydrate and hydroxylaminehydrochloride followed by the cyclization with concentrated sulfuric acid. Again, some indophenines (Gregory et al., 1993) were synthesized from thiophene and isatin by the standard procedure. Indophenines $\mathbf{2 a}$ and $\mathbf{2 b}$ were obtained when isatin reacts with thiophene under refluxing condition in the molar ratio of 2:1 respectively in the presence of concentrated sulfuric acid. Indophenines $3 a, 3 b, 4 a$ and $4 b$ were prepared under identical conditions (as $\mathbf{2 a}$ and $\mathbf{2 b}$ ) from 5-chloroisatin and 7-bromoisatin respectively. Again, indophenines $5 \mathbf{a}$ and $5 \mathbf{b}$ were prepared by the reaction between isatin and thiazol in the molar ratio of 2:1 in 


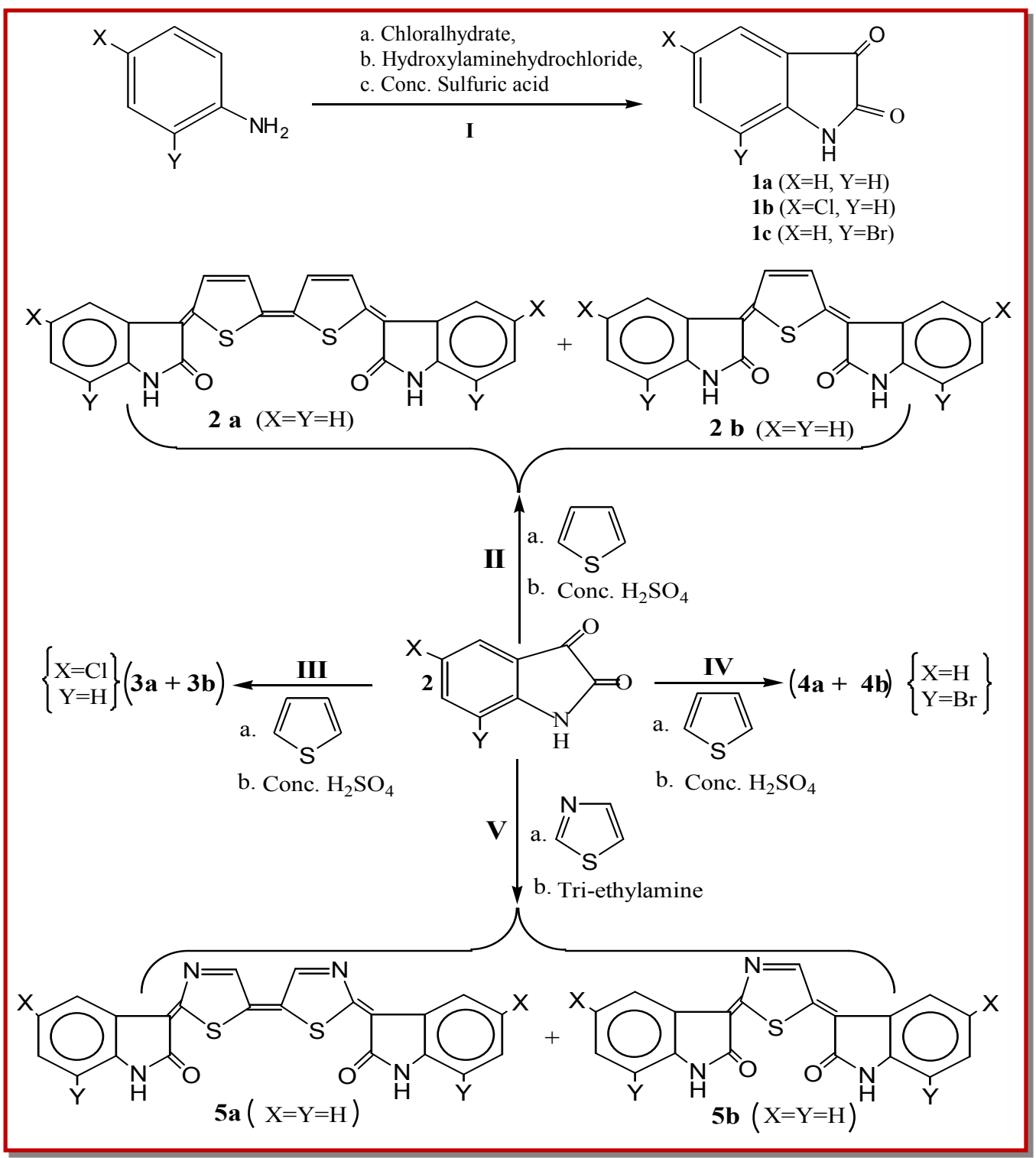

Scheme 1

presence of triethylamine under intensive stirring at $80^{\circ}$ C (Scheme 1). The cytotoxicity of the synthesized compounds was studied by brine shrimp lethality bioassay (Solis et al., 1993).

\section{Test animal}

Brine shrimps (Artemia Salina) were used as test animal for the investigation of cytotoxicity.

\section{Hatching and maintenance of brine shrimp}

The preferred condition for brine shrimp (temperature 28-30 ${ }^{\circ} \mathrm{C}$, salinity 30-35 ppt, $\mathrm{pH} 8-9$, and strong aeration) was established by mixing sodium chloride salts in water. After obtaining the desired condition, about one teaspoon of brine shrimp eggs was added to the beaker. After 12 hours hatching aggregated brine shrimp nauplii were collected in another beaker and rinse with fresh water and applied for testing.

\section{Preparation of test sample}

For the cytotoxicity study, dimethylsulphoxide (DMSO) was used as a solvent and the mortality of brine shrimp nauplii in this DMSO solution was almost zero. Different concentrations $(150,100$ and $50 \mu \mathrm{g} / \mathrm{mL})$ of each test samples were prepared with DMSO. Then 10-12 brine shrimp nauplii were transferred to each test tube using micropipette.

\section{Counting of nauplii}

The numbers of survived nauplii in each test tube were counted. The percentage of mortality of brine shrimp was calculated for each sample that gives different mortality for different concentrations. An approximate linear correlation was observed when logarithm of 
concentration was plotted against percentage of mortality and the values of $\mathrm{LC}_{50}$ were calculated for each sample. The $\mathrm{LC}_{50}$ represents the concentration of a compound, which will kill, or inactive 50 percent of the test animal. $\mathrm{LC}_{50}$ is inversely proportional to the toxicity of a compound, i.e. the lower the $\mathrm{LC}_{50}$ the higher the toxicity.

\section{Results}

Reaction I: After recrystallization, the products $\mathbf{1 a}, \mathbf{1 b}$ and 1c were obtained as brick-red solids with the yield of $90 \%$ and $\mathrm{m}$. p. ranging from $188^{\circ}-195^{\circ} \mathrm{C}$. The structures of the compounds are consistent with the physical constants and spectral data. The IR spectra of the compounds 1a-c show a sharp band at $1772 \mathrm{~cm}^{-1}$ corresponding to the $\mathrm{nC}=\mathrm{O}$ keto group and another sharp band at $1740 \mathrm{~cm}^{-1}$ indicates the $\mathrm{nC}=\mathrm{O}$ lactam. Again, the ${ }^{1} \mathrm{H}-\mathrm{NMR}$ signal for $>\mathrm{NH}$ is also observed in the respective region as a singlet and a signal for aromatic ring as multiplet.

Reaction II: The major product from crude mass afforded 2a in $60 \%$ yield, (deep blue, $\lambda_{\max } 625 \mathrm{~nm}$ ) after purification over silica gel column chromatography. IR: $\mathrm{n}_{\max }$ nujul (cm-1) $3450 \mathrm{~cm}^{-1}$ (m, sh, $\mathrm{nN}-\mathrm{H}$, lactam), 3100 $\mathrm{cm}^{-1}$ (sh, nC-H, aromatic), $1749 \mathrm{~cm}^{-1}$ (sh, $\left.\mathrm{nC}=\mathrm{O}\right), 1684$ $\mathrm{cm}^{-1} \quad(\mathrm{sh}, \mathrm{nC}=\mathrm{C})$ and 1605, $1508 \mathrm{~cm}^{-1}$ (sh, $\mathrm{nC}=\mathrm{C}$, aromatic); ${ }^{1}$ H-NMR: $\delta 10.5(\mathrm{~s}, 1 \mathrm{H}, \mathrm{N}-\mathrm{H}), 7.3-7.5(\mathrm{~m}, 4 \mathrm{H}$, alkene) and 6.9-7.0 (m, $8 \mathrm{H}$, aromatic); mass spectrum:

m/z 426 ( $\mathrm{M}^{\dagger}$, 25), 213 (33), 185 (20), 153 (100), 132 (38), 89 (20) and 77 (66). And $2 \mathbf{b}$ was afforded as minor product $\left(\lambda_{\max } 620 \mathrm{~nm}\right)$ in $15 \%$ yields which was brown in color with the melting point $260^{\circ}-265^{\circ} \mathrm{C}$ and also more polar comparing to 2a. IR: $3400 \mathrm{~cm}^{-1}$ (s, sh, $\mathrm{nN-H}$ ), $3050 \mathrm{~cm}^{-1}$ (sh, $\mathrm{nC}-\mathrm{H}$ aromatic), $1749 \mathrm{~cm}^{-1}$ (sh, $\left.\mathrm{nC}=\mathrm{O}\right)$ and $1670 \mathrm{~cm}^{-1}$ (sh, nC=C); ${ }^{1} \mathrm{H}-\mathrm{NMR}: \delta 10.4(\mathrm{~s}, 1 \mathrm{H}, \mathrm{N}-\mathrm{H}), 8.5$ (d, $2 \mathrm{H}$, alkene), 7.2-7.5 (m, $8 \mathrm{H}$, aromatic); mass spectrum: m/z $344\left(\mathrm{M}^{\dagger}, 40\right), 213$ (67), 185 (45), 153 (100), 132 (56), 89 (69), 77 (80).

Reaction III: The major product 3a was obtained as a blue solid having a yield of $45 \%\left(\lambda_{\max } 638 \mathrm{~nm}\right)$ with m.p. $>300^{\circ} \mathrm{C}$ after purification over silica gel column chromatography. The IR spectra of compound 3a show a band at $1670 \mathrm{~cm}^{-1}$ corresponding to the $\mathrm{C}=\mathrm{C}$ in the conjugated system and another strong band at $1749 \mathrm{~cm}^{-}$ 1 is observed for $\mathrm{C}=\mathrm{O}$. ${ }^{1} \mathrm{H}-\mathrm{NMR}$ : $\delta 10(\mathrm{~s}, 1 \mathrm{H}, \mathrm{N}-\mathrm{H})$, 6.7-

6.9 (m, 6H, aromatic); mass spectrum: m/z 494 ( ${ }^{+}$, 20), 247 (39), 187 (100), 166 (40), 89 (20) and 77 (60). Again, the minor product $3 \mathbf{b}$ was obtained as a brownish solid having a yield of $20 \%$. IR: $\mathrm{n}_{\max }$ nujul (cm -1) $3300 \mathrm{~cm}^{-1}$ (s, sh, $\left.\mathrm{nN}-\mathrm{H}\right), 3100 \mathrm{~cm}^{-1}$ (sh, $\mathrm{nC}-\mathrm{H}$, aromatic), $1747 \mathrm{~cm}^{-1}$ (sh, $\left.\mathrm{nC}=\mathrm{O}\right), 1682 \mathrm{~cm}^{-1}(\mathrm{sh}, \mathrm{nC}=\mathrm{C})$;
1H-NMR: $\delta 10.3$ (s, 1H, N-H), 7.2-7.4 (m, 6H, aromatic); mass spectrum: m/z $412\left(\mathrm{M}^{+}\right.$, 25), 247 (30), 219 (35), 187 (100), 89 (59) and 77 (60).

Reaction IV: The major product $4 \mathbf{a}$ was obtained as a blue solid in $55 \%$ yield $\left(\lambda_{\max } 650 \mathrm{~nm}\right)$ after purification over silica gel column chromatography. IR: $\mathrm{n}_{\max }$ nujul $\left(\mathrm{cm}^{-1}\right) 3312 \mathrm{~cm}^{-1}$ (s, sh, nN-H), $3100 \mathrm{~cm}^{-1}$ (sh, nC-H, aromatic), $1716 \mathrm{~cm}^{-1}$ (sh, $\left.\mathrm{nC}=\mathrm{O}\right), 1653 \mathrm{~cm}^{-1}$ (sh, $\left.\mathrm{nC}=\mathrm{C}\right)$; 1H-NMR: $\delta 11.4(\mathrm{~s}, 1 \mathrm{H}, \mathrm{N}-\mathrm{H}), 6.9-7.1$ (m, 6H, aromatic); mass spectrum: $\mathrm{m} / \mathrm{z} 582\left(\mathrm{M}^{+}, 15\right), 263$ (30), 231 (100), 89 (50) and 77 (70). Second product $4 \mathrm{~b}$ was obtained as brown solid, $\lambda_{\max } 620 \mathrm{~nm}$ and m. p. $220^{\circ}$ $225^{\circ} \mathrm{C}$. IR: $\mathrm{n}_{\max }$ nujul $\left(\mathrm{cm}^{-1}\right) 3450-3500 \mathrm{~cm}^{-1}(\mathrm{~m}, \mathrm{sh}, \mathrm{nN}-$ $\mathrm{H}), 3100 \mathrm{~cm}^{-1}$ (sh, nC-H, aromatic), $1716 \mathrm{~cm}^{-1}$ (sh, $\mathrm{nC}=\mathrm{O}), 1693 \mathrm{~cm}^{-1}$ (sh, $\left.\mathrm{nC}=\mathrm{C}\right) ;{ }^{1} \mathrm{H}-\mathrm{NMR}: \delta 9.3(\mathrm{~s}, 1 \mathrm{H}, \mathrm{N}-$ $\mathrm{H})$, 8.1-8.2 (d, 2H, alkene), 7.2-7.4 (m, 6H, aromatic);

mass spectrum: m/z 500( $\mathrm{M}^{\dagger}$, 40), 291 (54), 263 (40), 231 (100) and 155 (55).

Reaction V: The crude was chromatographed on silica gel column to separate the mixture which gives the major product 5 a as a blue solid in $50 \%$ yield, m. p. $290^{\circ}$ $-295^{\circ} \mathrm{C}$. IR: $\mathrm{n}_{\max }$ nujul $\left(\mathrm{cm}^{-1}\right) 3300 \mathrm{~cm}^{-1}$ (m, sh, $\mathrm{nN}-\mathrm{H}$, lactam), $3080 \mathrm{~cm}^{-1}$ (sh, $\mathrm{nC}-\mathrm{H}$, aromatic), $1716 \mathrm{~cm}^{-1}$ (sh, $\mathrm{nC}=\mathrm{O}), 1684 \mathrm{~cm}^{-1}$ (sh, $\left.\mathrm{nC}=\mathrm{N}\right), 1645$ (sh, $\left.\mathrm{nC}=\mathrm{C}\right) ;{ }^{1} \mathbf{H}-$ NMR: $\delta 10.0$ (s, 1H, N-H, lactam), 8.0 (s, 2H, alkene), 6.9

-7.0 (m, aromatic); mass spectrum: $\mathrm{m} / \mathrm{z} 428$ ( $\mathrm{M}^{+}$ 15), 214 (72), 186 (22), 154 (100), 132 (58), 89 (20) and 77 (21). Another product $5 \mathrm{~b}$ was obtained as brownish solid having a yield of $20 \%, \mathrm{~m}$. p. $175^{\circ}-180^{\circ} \mathrm{C}$. IR: $\mathrm{n}_{\max }$ nujul $\left(\mathrm{cm}^{-1}\right) 3450 \mathrm{~cm}^{-1}$ (m, sh, nN-H), $3063 \mathrm{~cm}^{-1}$ (sh, nC$\mathrm{H}$ aromatic), $1740 \mathrm{~cm}^{-1}$ (sh, $\left.\mathrm{nC}=\mathrm{O}\right), 1682 \mathrm{~cm}^{-1}$ (sh, $\mathrm{nC}=\mathrm{N}), 1670 \mathrm{~cm}^{-1}$ (sh, $\left.\mathrm{nC}=\mathrm{C}\right){ }^{1}{ }^{1} \mathrm{H}-\mathrm{NMR}$ : $\delta 10.5$ (s, $1 \mathrm{H}, \mathrm{N}$ $-\mathrm{H}), 9.0$ (s, 1H, a, $\mathrm{N}=\mathrm{CH}), 7.1-7.3(\mathrm{~m}, 8 \mathrm{H}$, aromatic); mass spectrum: $\mathrm{m} / \mathrm{z} 345\left(\mathrm{M}^{+}\right.$, 35), $214(46), 186(40)$, 154 (100), 89 (15) and 77 (35).

\section{Cytotoxicity}

The cytotoxicity study of the synthesized compounds was investigated on brine shrimp as a test organism and the $\mathrm{LC}_{50}$ values for the synthesized compounds are shown in Figure 1.

\section{Structure activity relationship (SAR)}

1. From the Figure 1, it is found that compound 1c shows the pronounced cytotoxicity property than that of $\mathbf{1 b}$. On the other hand, $\mathbf{1 b}$ had higher cytotoxicity property than 1a, the non-substituted isatin. Thus the order of cytotoxicity activity was $\mathrm{Br}>\mathrm{Cl}>\mathrm{H}$.

2. The indophenines $2 \mathbf{b}$ with the insertion of one 


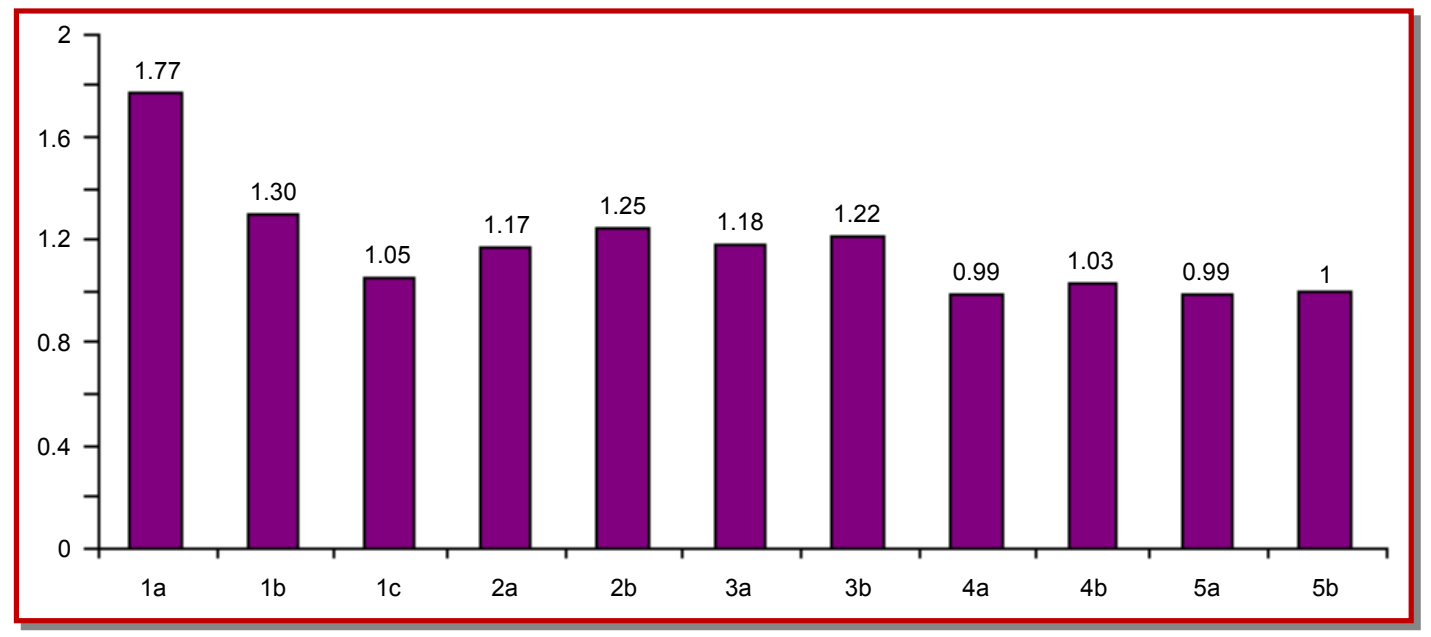

Figure 1: $\mathrm{LC}_{50}$ values of the synthesized compounds $\mathbf{1 a - 5 b}$

thiophene moiety showed enhanced cytotoxicity than 1a. The compound 2a with two thiophene moieties had still higher activity than $2 \mathbf{b}$.

3. The indophenines $4 \mathrm{a}$ and $\mathbf{4 b}$ with $\mathrm{Br}$ atom in $\mathrm{C}-7$ showed very high cytotoxicity that was similar to above trend.

4. Again the indophenines $3 \mathbf{a}$ and $3 \mathbf{b}$ with $\mathrm{Cl}$ atom in $\mathrm{C}$ 5 showed different cytotoxicity against brine shrimp nauplii, $3 \mathbf{a}$ showed greater cytotoxicity than $\mathbf{3 b}$ again the similar trend was observed.

5. The indophenines $5 \mathbf{a}$ and $5 \mathbf{b}$ also showed very high cytotoxicity. The cytotoxicity was enhanced due to the insertion of hetero atom $\mathrm{N}$ in the thiazol ring.

6. It is to be mention here that compounds $(2 a-5 b)$ with other heterocyclic systems like isatin-1,3,4thiadiazoline (Hossain et al., 2007) it was found that indophenines with thiophene moiety enhanced the cytotoxicity 24 times than isatin-1,3,4-thiadiazo-line.

\section{Discussion}

The indophenines (2a-b, 3a-b, $4 a-b$ and $5 a-b)$ have been synthesized from isatins, thiophene and thiazol in moderate yields. The products have been characterized with the help of spectral analysis from Japan (Tokushima University) and German (Ruhr University).

The SAR study of the synthesized compounds showed different cytotoxicity against brine shrimp. The chemical structure of a compound is very important as the relatively minor modification in the compound may results in major change in biological properties. The isatin 1a is almost inactive but the introduction of a chlorine atom in 5- position of the benzene ring (1b) enhanced the cytotoxicity. Again, insertion of a bromine atom in 7-position of the benzene ring (1c) further enhanced the cytotoxicity as $\mathbf{1} \mathbf{c}>\mathbf{1} \mathbf{b}>\mathbf{1 a}$, although the position of bromine and chlorine atoms are not identical. Indophenines $\mathbf{2 a}$ and $\mathbf{2 b}$ show higher cytotoxicity than that of isatins $\mathbf{1 a}, \mathbf{1 b}$ and $\mathbf{1 c}$ due to the presence of thiophene moieties. Again, the indophenine 2a with two thiophene moieties shows still higher cytotoxicity than that of $\mathbf{2 b}$ with one thiophene moiety. On the other hand, the indophenines $4 \mathrm{a}$ and $4 \mathrm{~b}$ show still greater cytotoxicity against brine shrimp nauplii than that of $3 \mathbf{a}$ and $\mathbf{3 b}$, due to the presence of bromine atom in the indophenines. Also the indophenines 5a and $5 \mathrm{~b}$ show very high cytotoxicity property against brine shrimp nauplii. The cytotoxicity enhancement is due to the presence of hetero atom $\mathrm{N}$ and $\mathrm{S}$ in the thiazol ring. Thus the compounds $1 c, 4 a, 4 b, 5 a$ and $5 b$ are very active and the compounds $2 \mathbf{a}, 2 \mathbf{b}, 3 \mathbf{a}$ and $3 \mathbf{b}$ are moderately active.

The present study shows that the cytotoxicity increases by the introduction of $\mathrm{Br}$ atom in the benzene ring than that of $\mathrm{Cl}$ atom and the greater is the numbers of heterocycles adjacent to the isatin ring, higher is the cytotoxicity. Especially the bulky molecules that contain two thiophene moieties have better cytotoxicity, which means, it hinders the replication of DNA molecule.

\section{Acknowledgement}

We express our sincere thanks to Dr. Khurshida Khayer of Jahangirnagar University, Bangladesh for supplying ${ }^{1} \mathrm{H}-\mathrm{NMR}$, ${ }^{13} \mathrm{C}-\mathrm{NMR}$ spectra of the compounds from Germany. We express our gratitude to Dr. Md. Mamun Hossain, Jahangirnagar University, Bangladesh for recording some of the IR and UV spectra of synthesized compounds. We are also grateful to Dr. Md. Rafiqul Islam for recording some ${ }^{1} \mathrm{H}-\mathrm{NMR}$ and mass spectra of the synthesized compounds from Japan.

\section{References}

Bhamaria RP, Deliwala CV. In vitro effect of 1-acyl-4alkyl-(or 


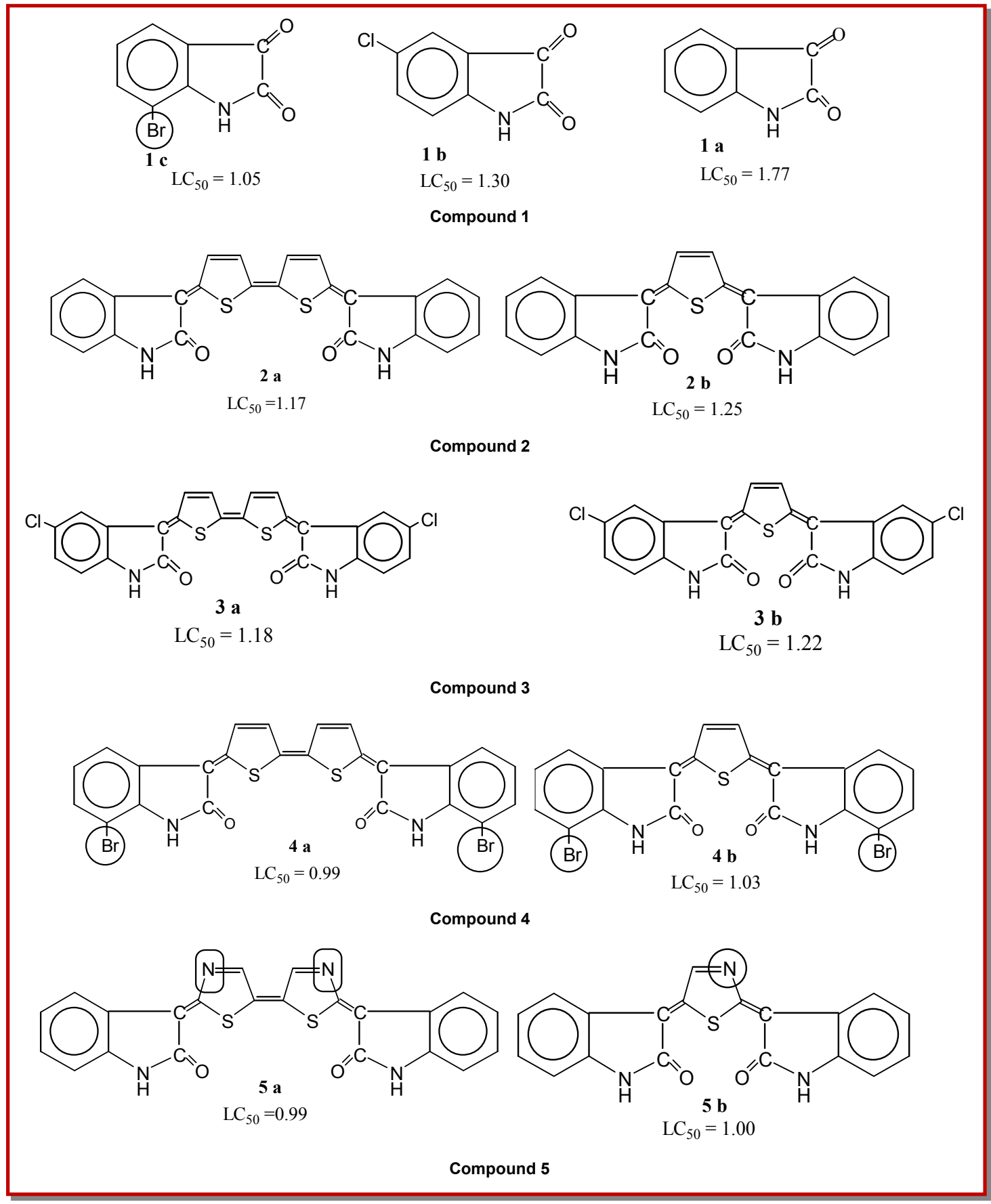

aryl)-thiosemicarbazides 1-(5-chlorosalisyl-idine)-4-alkyl-(or aryl)-thiosemicarba-zones and some hydrazones of 5chlorosalisyl-dehyde against pathogennic bacteria including mycobacterium tuberculosis (H37Rv). Indian J Exp Biol. 1968; 6: 62-63.

Chen H, Rhodes J. Schiff base forming drugs: Mechanisms of immune potentiation and therapeutic potential. J Mol Med. 1996; 74: 497-504. http://dx.doi.org/10.1007/BF00204975

Gregory VT, Kenneth $\mathrm{AB}$, Michael PC. The indophenine reaction revisited. J Am Chem Soc. 1993; 115: 11512-15. http://dx.doi.org/10.1021/ja00077a057
Holla BS, Rao BS, Shridhara K, Akberali PM. Studies on arylfuran derivatives. Part XI. Synthesis, characterization and biological studies on some Mannich base carrying 2,4dichlorophenylfurfural moiety. Farmaco 2000; 55: 338-44. http://dx.doi.org/10.1016/S0014-827X(00)00033-1

Hossain MM, Islam N, Khan R, Islam MR. Cytotoxicity study of dimethylisatin and its heterocyclic derivatives. Bangladesh J Pharmacol. 2007; 2: 66-70. http:// dx.doi.org/10.3329/bjp.v2i2.572

Islam MR, Abedin MJ, Duddeck H. Synthesis of 1-methyl bisdioxopyrolino $[2,3: 2,3: 2,3: 6,5]$ benzene and its heterocycles 
via thiocarbahydrazone, thiosemicarbazone. J Bangladesh Chem Soc. 1998; 11: 71-78.

Islam MR, Huda QMN, Duddeck H. Synthesis of some adamantine-1,2,4-triazole, -triazoline and -1,3,4-thiadiazoline derivatives. Indian J Chem. 1990; 29B: 376-78.

Meyer BN, Ferringni NR, Putnam JE, Jacobsen LB, Nichols DE, Melaughlin JL. Brine shrimp: A convenient general bioassay for bioactive plant constituents. Plant Medica. 1982; 45: 3134. http:/ / dx.doi.org/10.1055/s-2007-971236

Pal R, Jain K, Gupta GD, Handa RN, Puzari HK. Synthetic methods using isatin and derivatives. Indian J Chem. 1991; 30B: 1098.

Ram VJ, Raj AA, Ragunathan R, Raman R. Studies on conden- sed triazines as chemotherapeutic agents: Synthesis of 1, 2, 4triazino $[5,6-b]$ indoles and related compounds. Arch Pharmacol. 1980; 108: 313.

Sandmeyer T. Synthesis of isatin from aniline. Helv Chem Acta 1919; 2: 234.

Shaha GC, Khair K, Islam MR, Chowdhury MSK. Synthesis of thiocarbahydrazide, some thiocarba-hydrazone and their cyclised products as probes for pharmacological studies. Indian J Chem. 1992; 31B: 547-50.

Solis PN, Wright CW, Anderson MM, Gupta MP, Phillipson JD. A microwell cytotoxicity assays using Artemia salina (brine shrimp). Planta Med. 1993; 59: 250-52. http:// dx.doi.org/10.1055/s-2006-959661 